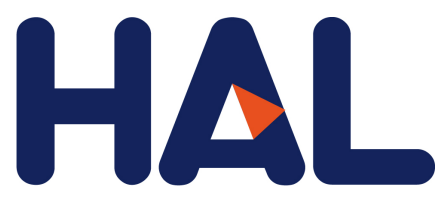

archives-ouvertes

\title{
Upper mantle deformation and seismic anisotropy in continental rifts
}

\author{
Alain Vauchez, Andrea Tommasi, Guilhem Barruol, Jerôme Maumus
}

\section{To cite this version:}

Alain Vauchez, Andrea Tommasi, Guilhem Barruol, Jerôme Maumus. Upper mantle deformation and seismic anisotropy in continental rifts. Physics and Chemistry of the Earth Part a Solid Earth and Geodesy, Elsevier, 2000, 25 (2), pp.111-117. 10.1016/S1464-1895(00)00019-3 . hal-02295622

\section{HAL Id: hal-02295622 \\ https://hal.archives-ouvertes.fr/hal-02295622}

Submitted on 25 Sep 2019

HAL is a multi-disciplinary open access archive for the deposit and dissemination of scientific research documents, whether they are published or not. The documents may come from teaching and research institutions in France or abroad, or from public or private research centers.
L'archive ouverte pluridisciplinaire HAL, est destinée au dépôt et à la diffusion de documents scientifiques de niveau recherche, publiés ou non, émanant des établissements d'enseignement et de recherche français ou étrangers, des laboratoires publics ou privés. 


\title{
Upper Mantle Deformation and Seismic Anisotropy in Continental Rifts
}

\author{
Alain Vauchez, Andréa Tommasi, Guilhem Barruol and Jerôme Maumus \\ Laboratoire de Tectonophysique, CNRS \& Université de Montpellier II, 34095 Montpellier, France
}

Received 24 September 1999; revised 1 December 1999; accepted 30 December 1999

\begin{abstract}
We investigate the seismic anisotropy signature of the continental rifting process. Several sources of anisotropy are considered: the lithospheric deformation, the asthenospheric flow, and the occurrence of oriented meltpockets in the asthenospheric mantle. Our results show that contrasted anisotropy patterns should be associated with the various conceptual models of rifting. Thus seismic anisotropy measurements may allow one to discriminate between these models. Anisotropy measurements in the Rio Grande, East-African and Rhine rifts suggest that these rifts formed by a transtensional deformation of the lithospheric mantle rather than by homogeneous extension of the lithosphere. Alignment of melt-lenses in the asthenospheric wedge may also account for a significant part of the seismic anisotropy recorded in the internal domains of these rifts. (C) 2000 Elsevier Science Ltd. All rights reserved.
\end{abstract}

\section{Introduction}

Rifting is a major tectonic process that deeply modifies continents and that, in favorable cases, may allow the growth of an oceanic basin. The mechanics of rifting however remains poorly understood. Contrasting tectonic models (McKenzie 1978, Nicolas, et al. 1994, Vauchez, et al. 1997, Wernicke 1981, Wernicke 1985) have been proposed to account for the extension and breakup of the continental lithosphere. This is largely a consequence of direct observation being mainly restricted to the upper crust. Investigation of deeper lithospheric levels relies essentially on indirect, geophysical approaches. In the last decade, the development of seismic tomography and anisotropy analysis techniques produced new data that may lead to significant advances on the understanding of architecture and dynamics of rift systems. In this paper, we focus on the seismic anisotropy data.

The relationship between seismic anisotropy and olivine LPO is well established; the polarization of the fast split shear wave is primarily controlled by the orientation of the olivine [100] axis. The maximum delay times are observed for shear waves propagating at high angle to both the [100] and [010] olivine axes (Mainprice and Silver 1993). Analysis of peridotites deformed in the dislocation creep regime in nature and experiments (Nicolas, et al. 1973, Zhang and Karato 1995, Ben Ismail and Mainprice 1998, Nicolas and Christensen 1987) as well as numerical modeling of LPO development in olivine polycrystals (Tommasi et al. in press, Wenk and Tomé 1999) show that the [100] and [010] axes of olivine tend to be preferentially aligned parallel to the flow direction and normal to the flow plane respectively. Thus seismic anisotropy data carry information on the deformation regimes in the upper mantle; it may help to discriminate between different tectonic models (Tommasi et al. 1999). However, the interpretation of seismic anisotropy data is not straightforward and requires a detailed analysis of all possible sources of anisotropy. Indeed, seismic anisotropy beneath rifts may result from various processes:

- the pre-rift deformation may be responsible for an inherited crystallographic fabric in the lithospheric mantle,

- the deformation associated with the rifting may modify the older fabric and generate a new, rift-related crystallographic fabric in the lithosphere,

- the flow of asthenospheric mantle beneath the rift may also produce a preferred orientation of mantle minerals, and - oriented melt pockets may develop in the asthenospheric wedge beneath the rift.

To evaluate the respective contribution of these various processes and, hence, to predict the seismic anisotropy that may be observed beneath a continental rift, one needs to predict the effect of each of them. In addition, it is necessary to evaluate how efficient is the upper mantle "memory", i.e., how long an anisotropic structure formed in the upper mantle may be preserved before being erased by subsequent processes. In this paper, we analyze the seismic anisotropy associated with the lithospheric and asthenospheric flow patterns predicted by different conceptual models of rifting. We also consider the anisotropy that may be produced by a preferential orientation of melt pockets in the partially molten asthenospheric mantle. The seismic anisotropy predictions for the different conceptual models are then compared to 
SKS splitting data in continental rifts.

\section{Pre-rift fabric}

Continental plates form through a succession of dispersion and accretion cycles. During these tectonic events, the entire lithosphere is deformed and an olivine LPO is generated in the lithospheric mantle. Subsequent cooling of the lithosphere freezes the LPO. If no subsequent deformation affects the lithosphere, this LPO may subsist for hundreds of $\mathrm{My}$. Long-lasting preservation of the crystallographic fabric in the lithosphere is strongly supported by olivine and pyroxenes LPO displayed by alpine-type lherzolite massifs (Barruol and Kern 1996, Peselnick, et al. 1974) or by mantle xenoliths brought up to the surface by basaltic or kimberlitic volcanism (Ben Ismail and Mainprice 1998, Ji, et al. 1994, Kern, et al. 1996, Mainprice and Silver 1993). Except from a few samples from cratonic environments, naturally deformed upper mantle rocks invariably display typical deformation LPO (Tommasi et al., in press), suggesting that post-tectonic static recrystallization generally does not modify significantly or erase a preexisting LPO.

The ubiquitous observation of seismic anisotropy, in particular SKS splitting (Silver 1996), and the good correlation of the anisotropy directions with the tectonic grain of continental domains are another data that support an efficient preservation of a frozen-in orogenic fabric, and therefore seismic anisotropy, in the lithospheric mantle. The most common shear wave anisotropy pattern observed in orogenic belts is a fast split shear wave polarized parallel to the strike of the belt and a relatively large time delay ( $\geq 1 \mathrm{~s})$

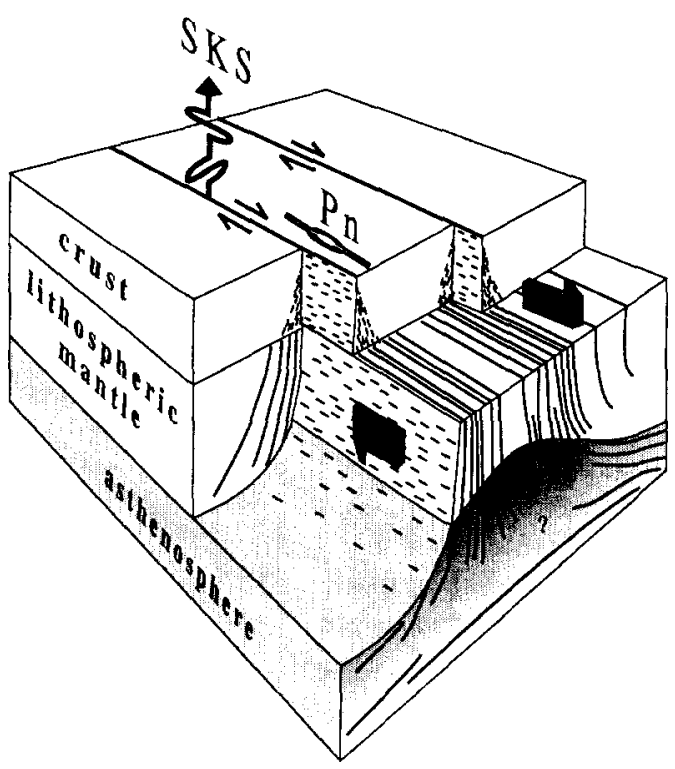

Figure 1. Idealized representation of a lithospheric-scale shear zone. Mantle flow in such a shear zone would occur along a steeply-dipping flow plane in a subhorizontal flow direction. Olivine [100] and [010] axis would reorient to approximate the flow direction and the normal to the flow plane respectively, resulting in a Pn fast propagation direction and a fast split shear wave polarization direction parallel to the trend of the shear zone between the fast and slow split shear waves arrivals (Silver 1996). These observations suggest an upper mantle fabric characterized by an alignment of olivine [100] axes parallel to the trend of the orogen and a vertical orientation of the olivine [001] axes. Pn anisotropy, although more sensitive to lateral heterogeneity, is usually in agreement with this interpretation (Smith and Ekström 1999). Simple shear or transpression in lithospheric-scale strike-slip faults (Fig. 1) are the most likely tectonic regimes to explain a coherence of such a LPO pattern over large areas (Tommasi et al., 1999).

Continental rifts tend to develop parallel to the preexisting orogenic fabric of the plates, systematically reactivating ancient lithospheric structures (e.g., initial rifting of the Atlantic and West Indian Oceans, and the Rio Grande, Baikal, East African, and Northeast China rifts (e.g., see Vauchez, et al. 1997). These observations suggest that rifts generally develop within a lithosphere structured during previous orogenic events. Therefore, beyond the domain where the lithosphere is actively deformed during rifting, an anisotropy representative of the pre-rift lithospheric fabric may be expected.

\section{Lithospheric deformation due to the rifting process}

During rifting, the whole lithosphere is stretched. Various tectonic models have been suggested to account for this lithospheric deformation. Because these models propose different deformation patterns, they should generate contrasted seismic anisotropy patterns. For each model, we simulate the lattice-preferred orientations (LPO) of olivine that may be produced in the lithosphere and in the asthenosphere using a self-consistent polycrystal plasticity model (Lebensohn and Tomé 1993). Comparison of modeled olivine LPO to LPO measured in experimentally and naturally deformed peridotites suggests that this model yields good predictions of olivine LPO development during upper mantle flow by dislocation creep (Tommasi et al. in press). The correlation is especially good when, as in the present simulations, the strain compatibility constrains are relaxed. Elastic properties of the deformed polycrystal are calculated as a Voigt-Reuss-Hill average of the olivine elastic stiffness coefficients $\left(C_{i j k l}\right)$ (Abramson, et al. 1997) over all crystal orientations. The Christofel equation is then used to predict velocities and polarization directions for $\mathrm{P}$ and $\mathrm{S}$-waves propagating in any direction relative to the structural fabric (Mainprice 1990).

McKenzie (1978) proposed a homogeneous extension of the whole lithosphere due to forces applied at plates' boundaries. According to this model, the lithospheric mantle would extend through pure shear, developing a lowangle foliation and an extensional lineation oriented normal to the rift axis (Fig. 2a). This deformation should produce an olivine LPO characterized by a concentration of [100] axes normal to the rift axis (Fig.2a) and an almost vertical orientation of the [010] axes. Such a LPO pattern would result in fastest propagation of $\mathrm{P}$-waves in a horizontal direction orthogonal to the rift axis, polarization of the fast split shear wave in a plane normal to the rift and small 

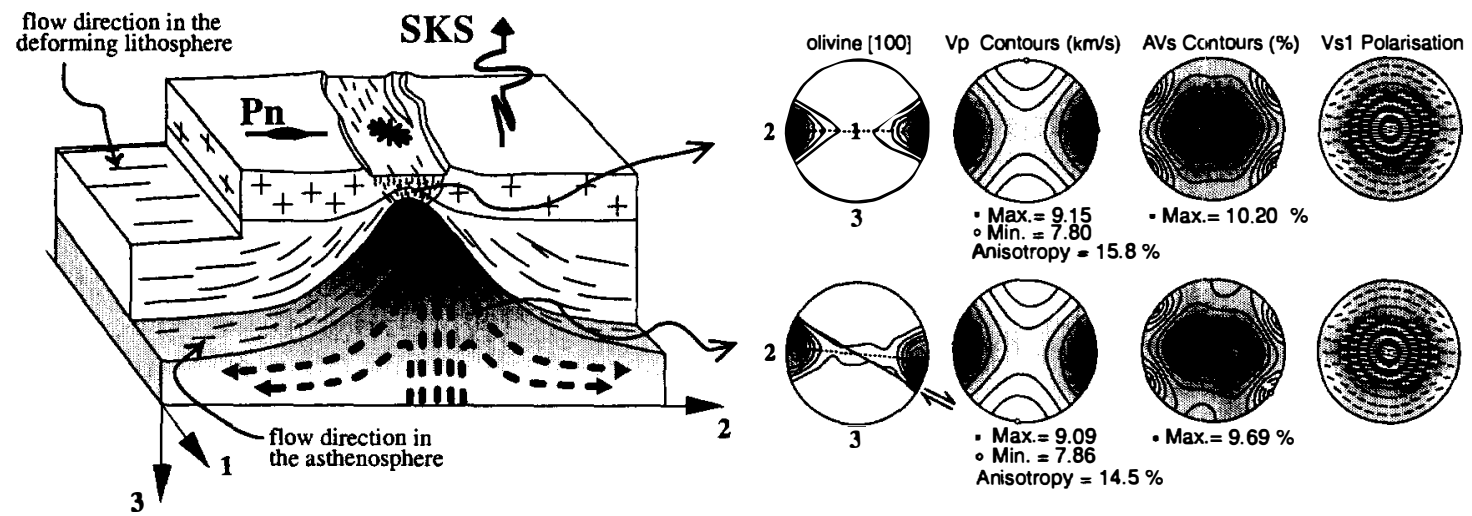

b

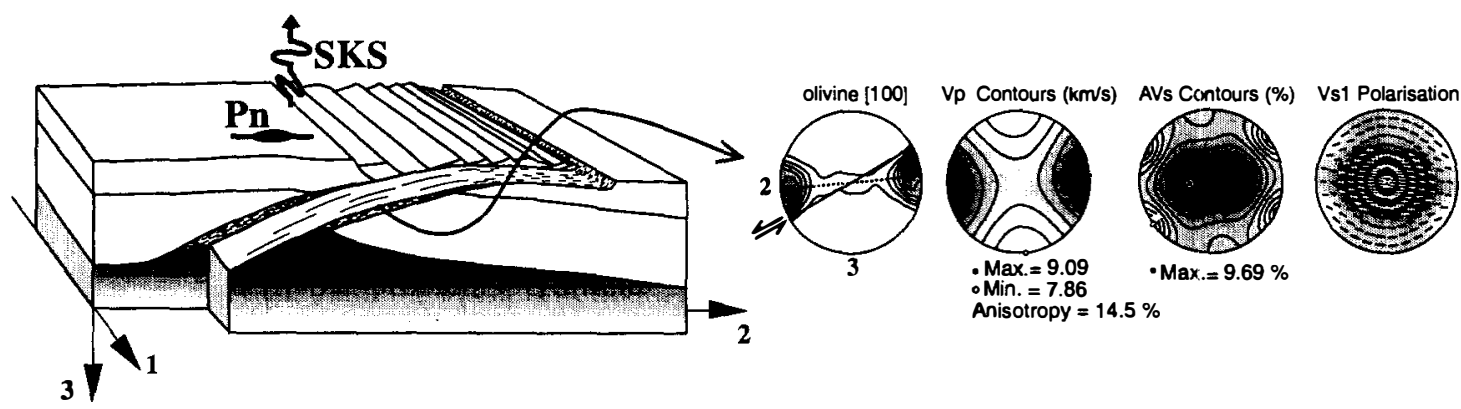

Figure 2. a: The rift model of McKenzie (1978) implies a homogeneous stretching of the lithosphere. b: The Wernicke (1981) model of lithospheric extension implies a deformation localized in a single lithospheric normal fault in which a simple-shear deformation regime prevails. For each model, we present the calculated olivine [100] preferred orientation, the P-wave velocity distribution, the S-wave anisotropy and the orientation of the fast split shear waves as equal-area stereographic projections in a vertical plane normal to the rift trend. Olivine LPO contouring is in multiples of a uniform distribution $(1,2,3 \ldots$ m.u.d. intervals), P-wave velocities at $0.2 \mathrm{~km} / \mathrm{s}$, S-wave anisotropy at $1 \%$ intervals. Inverse-log gray shading from white (minimum value) to black (maximum value).

delays between the fast and slow shear wave arrivals (Fig. 2a).

Wernicke (1981, 1985) proposed that extension may occur through simple shear along a lithospheric-scale lowangle normal fault (Fig. 2b). According to this model, the source of anisotropy just beneath the rift is not directly related to the rifting deformation since the rift structure is strongly asymmetric: the maximum extension of the lithospheric mantle is offset relative to the surface expression of the rift. The deformation is largely localized within the shear zone, and the thickness of material displaying a fabric due to the rift deformation is reduced. In the domain affected by the lithospheric normal fault, Pwaves would propagate faster in a direction orthogonal to the rift trend and shear wave splitting would be characterized by both a fast wave polarized in a plane orthogonal to the rift and small delay times (Fig. 2b). Indeed, we may speculate that the zone affected by shearing is small compared with the wavelength of the body-waves used in anisotropy measurements. The contribution of such deformation to the measured anisotropy is probably negligible.

Nicolas et al. (1994) proposed a model in which rifting develops by lithospheric rupture and rise of an asthenospheric wedge through the lithospheric mantle (Fig. $3 a$ ). Although these authors do not present in detail the processes that favor the emplacement of the asthenospheric wedge, one may speculate from their figures that the lithospheric deformation associated with the rifting process is very localized.
Finally, Vauchez et al. (1997) suggested that continent breakup occurs through a reactivation of the crystallographic fabric developed in the lithospheric mantle during previous orogenic events. Numerical models (Tommasi and Vauchez submitted) show that the preexisting olivine LPO tends to be reactivated in transtension, a deformation regime that combines strike-slip deformation and extension respectively parallel and orthogonal to the rift axis. These predictions are corroborated by a growing body of evidence supporting that transtension prevails during the early stages of rifting (Geoffroy and Angelier 1995, Geoffroy et al. 1994, Vauchez et al. 1997). This composite deformation regime results in a preferred orientation of olivine [100] axis significantly oblique on the trend of the rift (Fig. 3b). Consequently, the fast direction of propagation of $P n$ waves and the polarization of the fast split shear wave are oblique relative to the rift orientation (Tommasi et al. 1999). According to this model, an obliquity between the anisotropy orientation and the trend of the rift may therefore be expected in those domains where the lithospheric mantle was not totally eroded by the upwelling asthenosphere.

\section{Asthenospheric flow beneath the rift axes}

Thinning of the lithosphere and upwelling of hot asthenospheric material characterize active rifts. The flow of hot asthenospheric material may be a source of seismic anisotropy. Gao et al. (1997) suggested that diffusion processes accommodate deformation in the asthenosphere 
and thus no LPO forms. If such an assertion was true, anisotropy beneath mature rifts would not result from a preferred orientation of mantle minerals. There is, however, a large body of evidence that strong olivine LPO may form during deformation under asthenospheric conditions (Vauchez, et al. 1999). Peridotites from the Oman ophiolite (Nicolas 1989) or from the Zabargad Island (Nicolas et al. 1987) deformed at $\mathrm{T}>1200^{\circ} \mathrm{C}$ in the presence of melt display strong crystallographic fabrics (Fig.5). Surface waves measurements (Cara and Lévèque 1988, Nishimura and Forsyth 1989) consistently point to seismic anisotropy down to a minimum depth of $200 \mathrm{~km}$ beneath the oceans, i.e., at asthenospheric depths, even far away from mid oceanic ridges, where no melt is expected. We may therefore consider that asthenospheric flow generates olivine LPO and is a potential source of seismic anisotropy.

In both McKenzie (1978) and Wernicke (1981, 1985) models (Fig. 2a), the lithosphere is thinned over a broad domain. The asthenosphere raises beneath the axis of the rift and then flows away from the rift. This $2 \mathrm{D}$ flow pattern would result in a preferential alignment of olivine [100] in a vertical direction beneath the rift axis, and in a direction shallowly plunging normal to the rift trend outside the domain of upwelling mantle (Fig. 2a). The seismic anisotropy signature of such a LPO pattern would be easily discernable. In the center of the rift zone, above the upwelling asthenosphere, core shear waves (SKS, SKKS, PKS...) would display almost no splitting and Pn azimuthal anisotropy would be small. In contrast, away from the domain of upwelling mantle, the polarization of the fast split shear wave and the fastest propagation of $P$ waves would be normal to the rift (Fig. 2a).

In the Nicolas et al. (1994) model (Fig. 3a), asthenosphere upwelling occurs in small plumes in which mantle flow is vertical. Diverging from these conduits, the asthenospheric flow is channeled by the steep lithospheric walls and is therefore parallel to the rift. This model would result in an alignment of olivine [100] in a vertical direction in the conduits and parallel to the rift in domains where horizontal flow dominates (Fig. 3a). In these domains the resulting anisotropy would be large and characterized by fast split shear wave polarization and fast $\mathrm{Pn}$ propagation parallel to
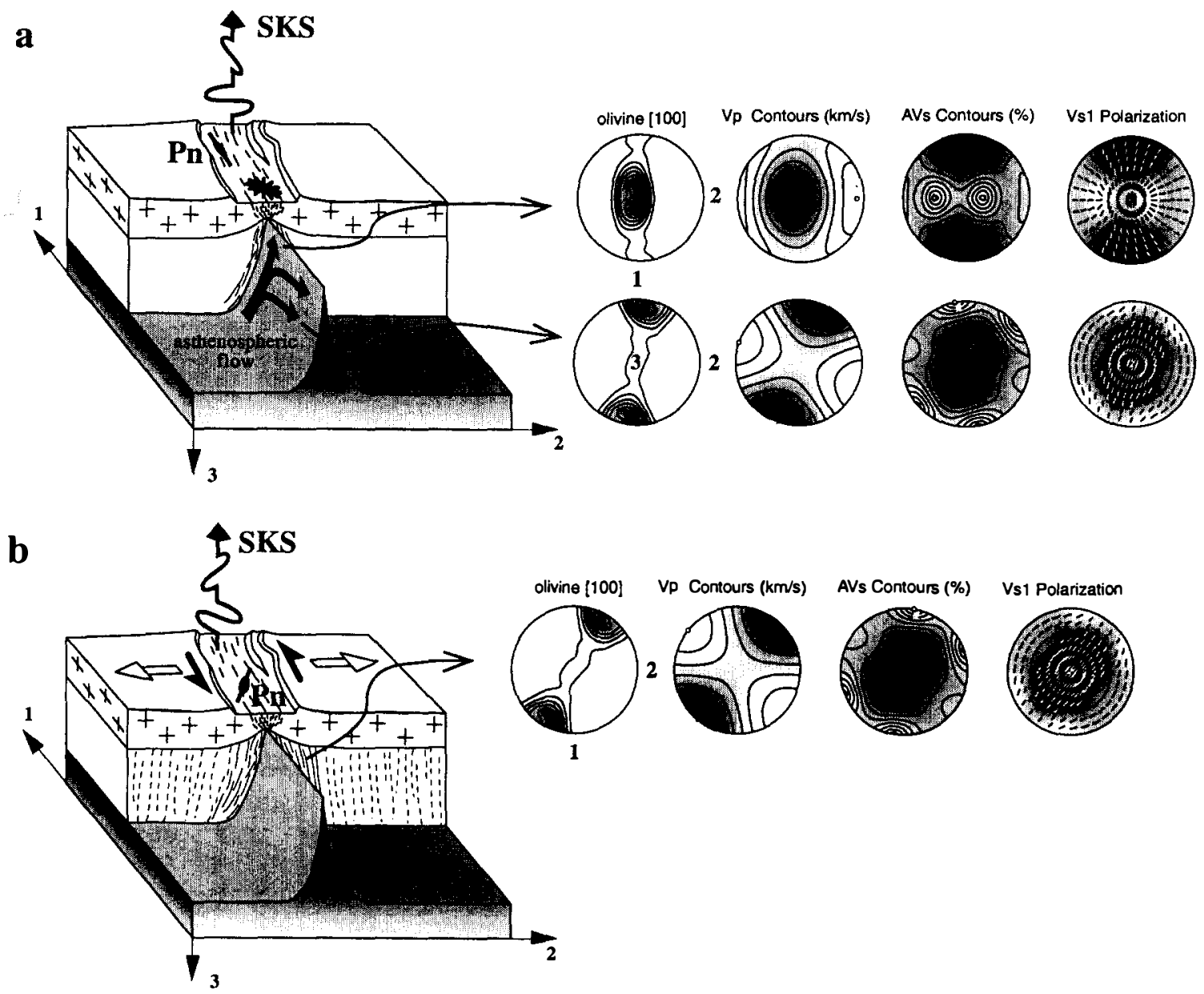

Figure 3. a: Nicolas et al (1994) model of rifting suggests a lithospheric rupture and therefore restricted lithospheric deformation. The asthenospheric flow is composed of small upwelling plumes (with vertical olivine lineation) and a horizontal flow channeled by the rift walls between these plumes characterized by horizontal olivine lineations. b: Vauchez et al (1997) and Tommasi and Vauchez (submitted) model suggests that major rifts develop through an association of strike-slip faulting and extension (transtensional deformation regime) reactivating a pre-existing fabric within the lithospheric mantle. This model may combine with Nicolas et al. (1994) one regarding the asthenospheric flow. For both models, the calculated olivine [100] preferred orientation, the P-wave velocity distribution, the S-wave anisotropy and the orientation of the fast split shear waves as equalarea stereographic projections the horizontal plane. Contouring as in Fig.2. 
the rift axes. Assuming that the diameter of the upwelling conduits is large enough (e.g., $>50 \mathrm{~km}$ ), domains displaying no SKS splitting and small Pn azimuthal anisotropy should be periodically detected.

\section{Shape preferred orientation of melt pockets}

Upward motion of hot asthenospheric mantle and the resulting deflection of isotherms beneath the rifts may generate partial melting. From seismological data, Achauer et al. (1994) and Gao et al. (1997) have respectively suggested that the asthenospheric wedge beneath the Kenya rift may contain $3-6 \%$ or $2-3 \%$ melt. Boudier (1978) has shown that, in deformed peridotites from the Lanzo massif, minerals crystallizing from melt form layers parallel to the foliation. This suggests that flow in the asthenospheric mantle results in anisometric melt pockets elongated in the flow plane. A control of the deformation of the solid matrix on the morphology and orientation of melt pockets has also been suggested from the analysis of both peridotites from the crust-mantle transition zone (Jousselin and Mainprice 1998) and gabbros from the Oman ophiolite (Lamoureux, et al. 1999).

We use Mainprice (1997) approach to estimate the anisotropy generated by the presence of anisometric melt pockets in the asthenospheric mantle. This approach allows to compute the full elastic behavior of a two-phases aggregate, taking into account the elastic properties, shape and orientation of the inclusions and the LPO of the minerals that constitute the solid matrix (Fig. 4). In the present study, the seismic properties of the matrix were

a. Typical LPO of a Zabargad peridotite (86Z25)

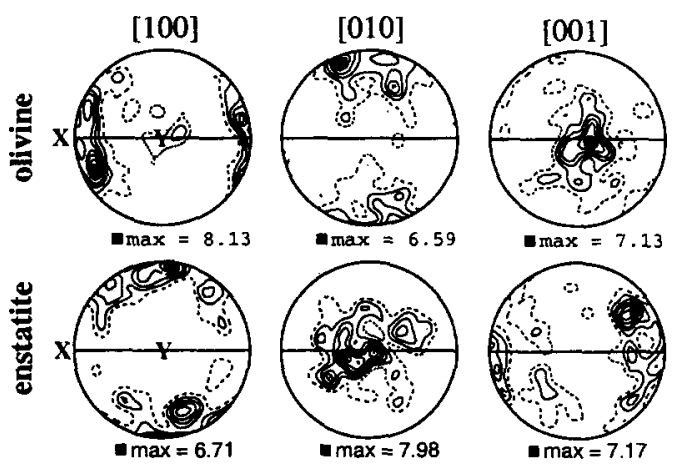

b. Average seismic properties of 5 Zabargad peridotite samples
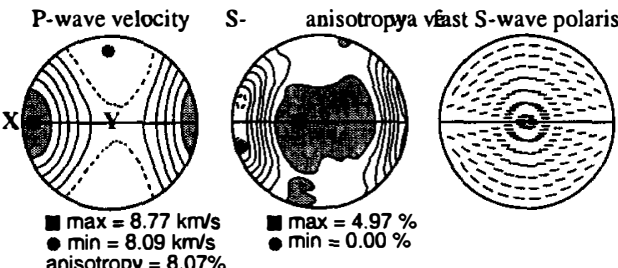

Figure 5: In order to calculate realistic seismic properties of the partially molten asthenosphere, LPO of olivine and orthopyroxene have been measured on Zabargad peridotite samples representative of the asthenospheric flow in the early stage of the Read Sea rifting. a: Olivine and enstatite LPO of a typical sample (86Z25). b: Average seismic properties (five samples) used in the simulations in order to smooth small variations in microstructure and in rock comoosition. Contouring as in Fig.2.

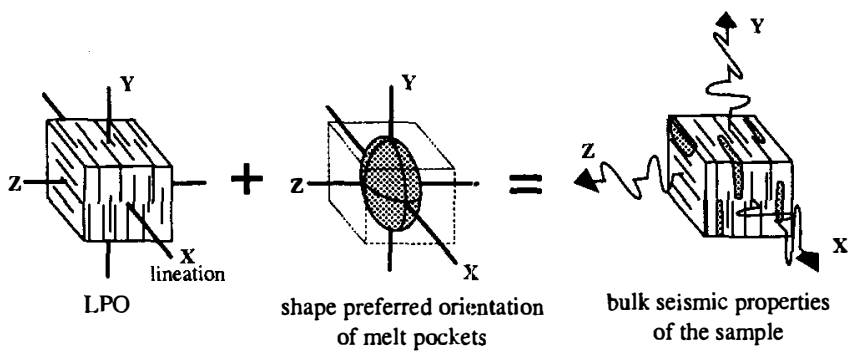

Figure 4: Outline of the Mainprice (1997) approach used to calculate the complete elastic tensor of a polycrystalline aggregate containing anisometric melt pockets. The crystalline aggregate elastic properties are computed using the LPO of the constituent minerals. The melt is characterized by its volume fraction and by the shape ratio of the melt pockets, considered as ellipsoids.

computed from the LPO measured on 5 peridotites from the Zabargad Island (Fig. 5; Maumus, et al. 1998) known to have been deformed under asthenospheric conditions during the early stages of the Red Sea rifting. For simplicity sake, melt pockets were assumed to have ellipsoidal shapes flattened in a direction normal to the foliation. Their shape ratio was successively set as 2:2:1, 5:5:1, 10:10:1 and $20: 20: 1$. The melt fraction in the matrix was varied from 0 to $10 \%$.

The results of these simulations (Fig. 6) show that both the melt fraction and the shape ratio of the melt pockets combine to determine the anisotropy generated in the partially molten mantle beneath rifts. An increase in the melt fraction alone does not increase significantly the anisotropy of the aggregate if melt is contained in isometric or weakly anisometric pockets. On the other hand, even a few percent of melt (e.g., 4\%) collected in thin lenses

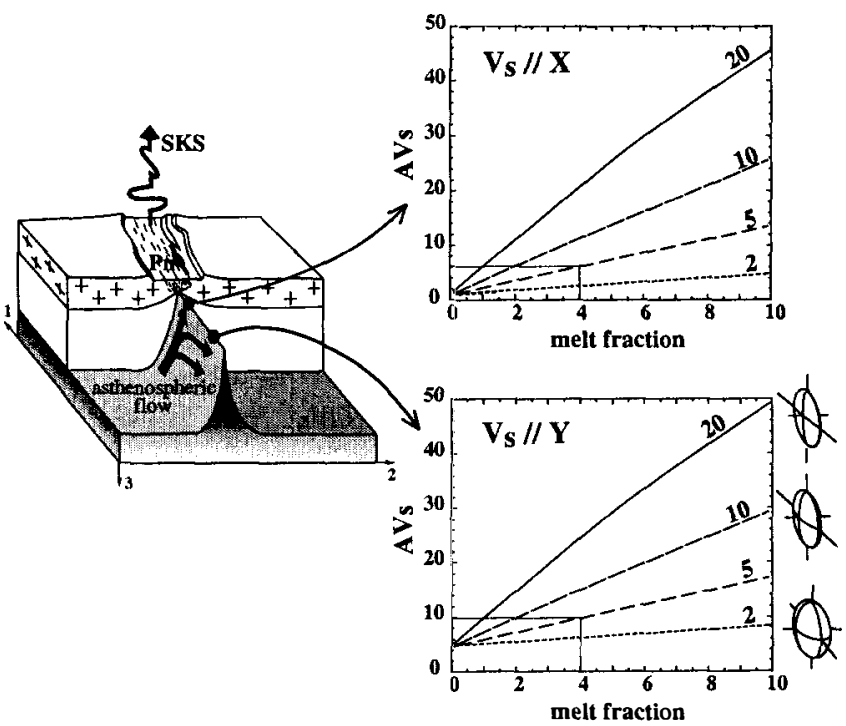

Figure 6: Combined effect of vertically oriented melt pockets and olivine LPO in the asthenospheric mantle on the seismic anisotropy beneath rifts. In these calculations, the crystalline matrix has the averaged seismic properties shown in Figure 5. The melt fractions vary between 0 and $10 \%$ and the melt pockets display shape ratios varying from $2(2: 2: 1)$ to $20(20: 20: 1)$. We plot the shear wave anisotropy along the $\mathrm{X}$ direction (that could be sampled by SKS waves travelling vertically across the upwelling asthenosphere) and the $\mathrm{Y}$ structural direction (sampled by SKS waves crossing the horizontally flowing asthenosphere). In the absence of melt, the anisotropy in regions of upwelling mantle is verv weak 

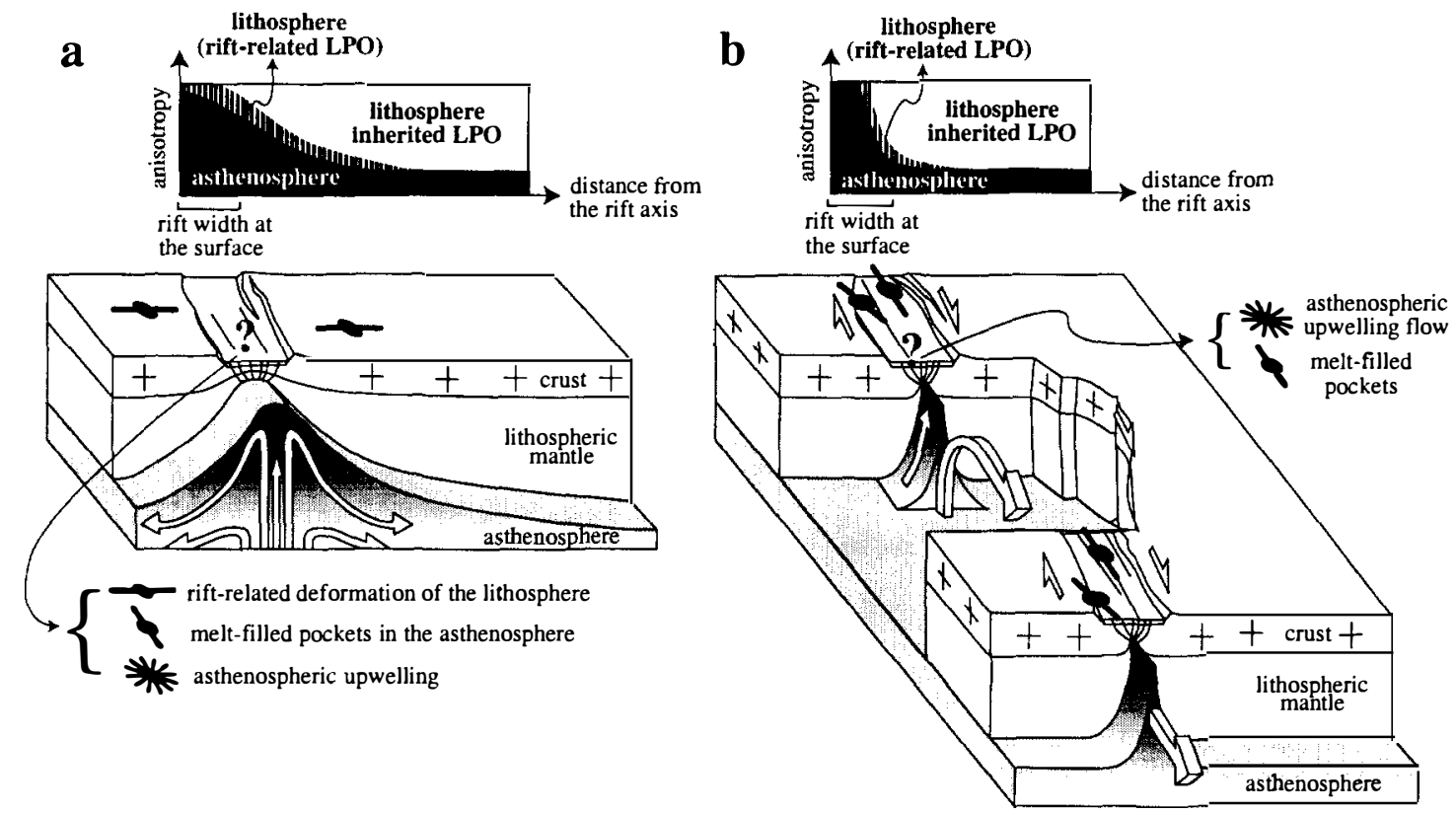

Figure 7: These cartoons illustrate two contrasting rifting models. In the first case (a), the lithosphere is homogeneously stretched in a direction normal to the rift axis. Both the asthenospheric and the lithospheric anisotropy will constructively interfere and will be hard to separate. The anisotropy is expected to trend normal to the rift not only within the rift but also beyond the rift shoulders. In the second case (b), the rifting is controlled by the pre-existing (frozen) structure of the lithosphere and the lithosphere should deform by transtension. The asthenospheric contribution to the measured anisotropy is dominant beneath the rift axis; this contribution is expected to be weak above the regions of asthenospheric upwelling and rather strong and oriented parallel to the rift between these regions. Beyond the rift shoulders, the anisotropy should be primarily related to the preexisting structure of the lithospheric mantle.

parallel to the foliation can double the anisotropy produced by the mineral LPO. This strongly suggests that melt lenses may significantly contribute to seismic anisotropy in the rift itself.

\section{Discussion and conclusions}

Continental rifting is a complex process involving deformation of the lithosphere, asthenospheric flow, and partial melting. All these processes may result in seismically anisotropic structures. None of the potential sources of anisotropy may be a-priori ruled out. It is more likely that the observed anisotropy is a combination of the various contributions, the proportion of which may vary from one rift to the other and also within a single rift, depending on the degree of evolution of the rifting process. As an attempt to summarize our analysis, we present in Figure 7 the possible contribution of the various sources of anisotropy for the two main models of rifting: the transtensional lithospheric rupture model (Nicolas, et al. 1994, Vauchez, et al. 1997, Vauchez, et al. 1998, Tommasi and Vauchez submitted) and the McKenzie (1978) model. In the first case (Fig. 7b), asthenospheric flow is restricted to the rift axis and generates a fast axis of anisotropy (fast direction of propagation of $\mathrm{Pn}$ waves and direction of polarization of the fast split shear wave) oriented parallel to the rift. On the other hand, in the McKenzie's model (Fig. 7a), the asthenospheric flow may generate an anisotropy even beyond the trace of the rift at the surface and the fast axis is in this case normal to the rift trend. For both models, beneath the active part of the rift, an anisotropy due to preferentially oriented anisometric melt-pockets may add to the asthenospheric LPO-induced anisotropy.
Away from the rift axes, the contribution of the rift-related lithospheric deformation would increase. If rifting occurs by lithospheric rupture, as suggested by Nicolas et al. (1994), the lithospheric anisotropy is similar to the anisotropy induced by the asthenospheric flow along the rift axis and by oriented melt-pockets. A transtensional breakup, as suggested by Vauchez et al. (1997), will result in an obliquity of the olivine [100] axis preferred orientations and, hence, of the seismic anisotropy relative to the rift trend. On the other hand, the McKenzie (1978) model predicts a rift-related lithospheric deformation characterized by a flow direction normal to the rift axis. This would result in a preferential alignment of olivine [100] axis and a resulting fast axis of anisotropy normal to the rift.

Seismic anisotropy measurements in rift zones are scarce and they are generally limited to the central domain of the rift basin. Thus our model predictions cannot be fully tested. Yet analysis of SKS splitting data in the Rio Grande, East African, Rhine and Baikal rifts on the light of our model results allows one to discriminate between the different conceptual models. The Rio Grande Rift is characterized by an orientation of the fast split shear wave polarization slightly oblique or sub-parallel to the trend of the rift (Sandvol, et al. 1992). The East-African rift displays fast shear wave polarization planes significantly oblique or, more seldom, parallel to the rift axis in-between the rift shoulders and the few measurements performed beyond the shoulders show fast shear waves polarized roughly parallel to the pre-rift orogenic fabric (Gao 1997). The Rhine graben (Granet, et al. 1998) differs from the previous examples since it is a case where the rift formed oblique to the inherited hercynian fabric. Within the rift shoulders, the 
fast split shear wave is polarized parallel to the rift trend. Away from the graben, it parallels the hercynian tectonic grain. The Baikal rift displays a complex pattern of anisotropy (Gao, et al. 1994) characterized by domains with a polarization of the fast split shear wave either parallel or at high angle to the rift direction.

None of the Rio Grande, East-African and Rhine rifts anisotropy patterns is in agreement with McKenzie (1978) or Wernicke $(1981,1985)$ models. The consistent obliquity of the polarization direction of the fast shear wave on the rift trend observed in the East African and Rio Grande rifts rather favors a transtensional deformation of the lithosphere during rifting. Thus, a model of lithospheric rupture associating ductile transtension of the lithosphere in the early stages of rifting and asthenospheric flow dominantly parallel to the rift axis, with or without preferential orientation of melt lenses parallel to the flow plane in the asthenosphere, would account for most anisotropy observations within rifted domains. In contrast, the complex repartition of fast SKS polarization directions observed in the Baikal rift remains difficult to interpret from a tectonic point of view. Finally, in all cases, beyond the rift shoulders, the measured seismic anisotropy displays a strong influence of the inherited fabric.

\section{References}

Abramson, E. H., Brown, M., Slutsky, L. J., and Zaug, J. (1997) The elastic constants of San Carlos olivine up to $17 \mathrm{GPa}$, J. Geophys. Res., $102,12,252-12,263$.

Achauer, U. and KRISP working group (1994) New ideas on the Kenya rift based on the inversion of the combined dataset of the 1985 and 1989/90 seismic tomography experiment, Tectonophysics, '236, 305329.

Barruol, G. and Kern, H. (1996) Seismic anisotropy and shear-wave splitting in lower-crustal and upper-mantle rocks from the Ivrea zone experimental and calculated data, Phys. Earth Planet. Inter., 95, 175194.

Ben Ismail, W. and Mainprice, D. (1998) An olivine fabric database: an overview of upper mantle fabrics and seismic anisotropy, Tectonophysics, 296, 145-158.

Boudier, F. (1978) Structure and petrology of the Lanzo massif (Piedmont Alps), Geol. Soc. Am. Bull., 89, 1574-1591.

Cara, M. and Léveque, J. L. (1988) Anisotropy of the asthenosphere: The higher mode data of the Pacif revisited, Geophysical Research Letters, 15, 205-508.

Gao, S., Davis, P. M., Liu, H., Slack, P. D., Rigor, W., Zorin, Y. A., Mordvinova, V. V., Kozhevnikov, V. M., and Logatchev, N. A. (1997) SKS splitting beneath continental rift zones, J. Geophys. Res., 102, 22781-22797.

Gao, S., Davis, P. M., Liu, H., Slack, P. D., Zorin, Y. A., Mordvinova, V. V., Kozhevnikov, V. M., and Meyer, R. P. (1994) Seismic anisotropy and mantle flow beneath the Baikal rift zone, Nature, 371, 149-151.

Geoffroy, L., Bergerat, F., and Angelier, J. (1994) Tectonic evolution of the Greenland-Scotland Ridge during the Paleogene; new constraints, Geology, 22, 653-656.

Granet, M., Glahns, A., and Achauer, U. (1998) Anisotropic measurements in the Rhine graben area and the French Massif Central, Pure Appl. Geophys., 151, 333-364.

Ji, S., Zhao, X., and Francis, D. (1994) Calibration of shear-wave splitting in the subcontinental upper mantle beneath active orogenic belts using ultramafic xenoliths from the Canadian cordillera and Alaska, Tectonophysics, 239, 1-27.

Jousselin, D. and Mainprice, D. (1998) Melt topology and seismic anisotropy in mantle peridotites of the Oman ophiolite, Earth Planet. Sci. Lett.., 164, 553-568.

Kern, H., Burlini, L., and Ashchepkov, I. V. (1996) Fabric-related seismic anisotropy in upper-mantle xenoliths: evidence from measurements and calculations, Phys. Earth Planet. Inter., 95, 195-209.

Lamoureux, G., Ildefonse, B., and Mainprice, D. (1999) Modelling the seismic properties of fast-spreading ridge crustal LVZ : insights from Oman gabbro textures, Tectonophysics, 312, 283-301.

Lebensohn, R. A. and Tomé, C. N. (1993) A self-consistent anisotropic approach for the simulation of plastic deformation and texture development of polycrystals: Application to zirconion alloys, Acta metallurgica materialia, 41, 2611-2624.

Mainprice, D. (1990) A FORTRAN program to calculate seismic anisotropy from the lattice preferred orientation of minerals, Computers \& Geosciences, 16, 385-393.

Mainprice, D. (1997) Modelling anisotropic seismic properties of partially molten rocks found at mid-ocean ridges, Tectonophysics, 279, 161-179.

Mainprice, D. and Silver, P. G. (1993) Interpretation of SKS-waves using samples from the subcontinental lithosphere, Phys. Earth Planet. Inter., $78,257-280$.

Maumus, J., Barruol, G., and Vauchez, A. (1998) Influence of crystallographic fabrics and partial-met on shear wave splitting in rift areas, EOS, $A G U$ fall meeting, vol. 79, p. 580

McKenzie, D. (1978) Some remarks on the development of sedimentary basins, Earth Planet. Sci. Lett., 40, 25-32.

Nicolas, A. (1989) Structures of ophiolites and dynamics of oceanic lithosphere, 367 pp., Kluwer Academic Publishers, Dordrecht.

Nicolas, A., Achauer, U., and Daignieres, M. (1994) Rift initiation by lithospheric rupture, Earth Planet. Sci. Lett., 123, 281-298.

Nicolas, A., Boudier, F., and Boullier, A. M. (1973) Mechanism of flow in naturally and experimentally deformed peridotites, American Journal of Science, 273, 853-876.

Nicolas, A., Boudier, F., and Montigny, R. (1987) Structure of Zabargad island and early rifting of the red sea, J. Geophys. Res., 92, 461-474.

Nicolas, A. and Christensen, N. I., Formation of anisotropy in upper mantle peridotites - A review, in Composition, structure and dynamics of the lithosphere-asthenosphere system, vol. 16, edited by K. Fuchs and C. Froidevaux, pp. 111-123, AGU, Washington, D.C. (1987).

Nishimura, C. E. and Forsyth, D. W. (1989) The anisotropic structure of the upper mantle in the Pacific, Geophys. J., 96, 203-230.

Peselnick, L., Nicolas, A., and Stevenson, P. R. (1974) Velocity anisotropy in a mantle peridotite from the Ivrea Zone: Application to upper mantle anisotropy, J. Geophys. Res., 79, 1175-1182.

Sandvol, E., Ni, J., Ozalaybey, S., and Schlue, J. (1992) Shear-wave splitting in the Rio Grande rift, Gedphysical Research Letters, 19, 2337. 2340.

Silver, P. G. (1996) Seismic anisotropy beneath the continents: Probing the depths of geoloy, Ann. Rev. Earth Planet. Sci., 24, 385-432.

Smith, G. P. and Ekström, G. (1999) A global study of $P n$ anisotropy beneath continents, J. Geophys. Res., 104, 963-980.

Tommasi, A., Mainprice, D., Canova, G., and Chastel, Y. (2000) Viscoplastic self-consistent and equilibrium-based modeling of olivine lattice preferred orientations. 1. Implications for upper mantle seismic anisotropy, J. Geophys. Res., in press.

Tommasi, A., Tikoff, B., and Vauchez, A. (1999) Upper mantle tectonics: Three-dimensional deformation, olivine crystallographic fabrics and seismic properties, Earth Planet. Sci. Lett., 168, 173-186.

Vauchez, A., Barruol, G., and Nicolas, A. (1999) Comment on "SKS splitting beneath rift zones", J. Geophys. Res., 104, 10787-10790.

Vauchez, A., Barruol, G., and Tommasi, A. (1997) Why do continents break up parallel to ancient orogenic belts?, Terra Nova, 9, 62-66.

Vauchez, A., Tommasi, A., and Barruol, G. (1998) Rheological heterogeneity, mechanical anisotropy, and tectonics of the continental lithosphere, Tectonophysics, 296, 61-86.

Wenk, H.-R. and Tomé, C. (1999) Modeling dynamic recrystallization of olivine, J. Geophys. Res., submitted.

Wernicke, B. (1981) Low angle normal faults in Bassin and Range province. Nappe tectonics in an extending orogen, Nature, 291, 645648 .

Wernicke, B. (1985) Uniform-sense normal simple shear of the continental lithosphere, Canadian Journal of Earth Sciences, 22, 108-125.

Zhang, S. and Karato, S. (1995) Lattice preferred orientation of olivine aggregates in simple shear, Nature, 375, 774-777. 